\title{
PENGARUH STRUKTUR ASET, PROFITABILITAS, PERTUMBUHAN PERUSAHAAN DAN UKURAN PERUSAHAAN TERHADAP STRUKTUR MODAL PADA PERUSAHAAN MANUFAKTUR DI SEKTOR INDUSTRI BARANG DAN KONSUMSI
}

\author{
Syafril, Muhammad Fahmi \\ Asmi Citra Nusantara Banjarmasin \\ syafril99riau@gmail.com
}

\begin{abstract}
This study aims to determine the effect of Asset Structure, Profitability, Company Growth and Company Size on the Capital Structure of Manufacturing Companies in the Goods and Consumption Industry Sector Listed on the Indonesia Stock Exchange (BEI) Period 2017 - 2019. This study uses a sample of 26 manufacturing companies in the goods and consumption industry sector which is listed on the Indonesia Stock Exchange (IDX) period 2017 - 2019. The data used are secondary data obtained from the site www.idx.co.id. The sampling method is purposive sampling. The data analysis method used is multiple linear regression. The results of this study, it is known that partially the structure of the Asset Structure has a Significant Effect on the Capital Structure, while the Profitability, Company Growth and Company Size variables do not have a Significant Effect on the Capital Structure. Simultaneously the independent variables Asset Structure, Profitability, Company Growth and Company Size have a Significant Effect on the Capital Structure of Manufacturing Companies in the Goods and Consumption Industry Sector on the Indonesia Stock Exchange Period 2017-2019
\end{abstract}

Keywords: Capital Structure; Asset Structure; Profitability; Company Growth; Company Size

\begin{abstract}
Abstrak
Penelitian ini bertujuan untuk mengetahui pengaruh struktur aset, profitabilitas, pertumbuhan perusahaan dan ukuran perusahaan terhadap struktur modal pada perusahaan manufaktur di sektor industri barang dan konsumsi yang terdaftar di Bursa Efek Indonesia (BEI) Periode 2017 - 2019. Penelitian ini menggunakan sampel dari 26 perusahaan manufaktur di sektor industri barang dan konsumsi yang terdaftar di Bursa Efek Indonesia (BEI) periode 2017 - 2019. Data yang digunakan adalah data sekunder yang diperoleh dari situs www.idx.co.id. Metode pengambilan sampel adalah purposive sampling. Metode analisis data yang digunakan adalah regresi linier berganda. Hasil penelitian ini, diketahui bahwa secara parsial struktur struktur aktiva memiliki pengaruh signifikan terhadap struktur modal, sedangkan
\end{abstract}


variabel profitabilitas, pertumbuhan perusahaan dan ukuran perusahaan tidak memiliki pengaruh signifikan terhadap struktur modal. Secara simultan variabel independen struktur aset, profitabilitas, pertumbuhan perusahaan dan ukuran perusahaan memiliki pengaruh signifikan terhadap struktur modal perusahaan manufaktur di sektor industri barang dan konsumsi di Bursa Efek Indonesia Periode 2017-2019

Kata Kunci : struktur modal; struktur aktiva; profitabilitas, pertumbuhan perusahaan; ukuran perusahaan

\section{PENDAHULUAN}

Globalisasi telah mengubah persaingan antar perusahaan yang tanpa batas negara di mana suatu negara terhubung satu dengan negara lainnya. Kemajuan terknolgi di bidang informasi telah berhasil mengubah bentuk suatu bisnis. Perusahaan yang berskala global mempunyai kekuatan untuk menguasai pangsa pasar suatu negara. Persaingan global yang semakin kuat, menuntut para manajer perusahaan untuk meningkatkan produktivitas dan menetapkan strategi perusahaan dalam menghadapi persaingan global agar perusahaan memperoleh keuntungan yang optimal dengan mengunakan semua sumber daya yang dimiliki perusahaan (Tauhid, 2018). Kegiatan tersebut berkaitan dengan usaha perusahaan dalam memaksimalkan keuntungan. Tujuan utama dari perusahaan adalah untuk memaksimalkan kesejahteraan dan keuntungan para pemegang saham (Brigham dan Houston, 2006). Dalam memenuhi tujuan tersebut, maka diperlukan pengambilan keputusan yang tepat bagi perusahaan dalam berinvestasi, keputusan dalam memperoleh pendanaan, dan keputusan dalam pembagian dividen (Syafril, 2019)

Menurut Suad Husnan (2014), struktur modal adalah perimbangan atau perbandingan antara jumlah hutang jangka panjang dengan modal sendiri. Struktur modal menjelaskan bagaimana cara perusahaan mendanai aset mereka melalui kombinasi dana yang terdiri dari modal sendiri dan modal asing yang digabungkan untuk membiayai operasional perusahaan.

Salah satu tujuan perusahaan adalah meningkatkan nilai perusahaan yang dapat di lakukan melalui keputusaan pendanaan dan investasi. Menurut Modigliani - Miller dalam (Hanafi, 2004: 299), menyatakan bahwa nilai perusahaan dengan utang lebih tinggi dibandingkan nilai perusahaan tanpa utang. Kenaikan nilai tersebut dikarenakan adanya penghematan pajak dari penggunaan utang. Sisi hutang (liabilitas) merupakan sumber pendanaan perusahaan yang berasal dari pihak asing berupa pinjaman (debt financing). Penggunaan dana asing akan meningkatkan leverage keuangan perusahaan dan memiliki beban bunga yang harus dibayar setiap periode tertentu (Hidayat, 2013).

Sumber dana dari modal sendiri adalah modal yang berasal dari pemilik perusahaan dan dana yang berasal dari keuntungan yang dihasilkan perusahaan 
biasanya dari laba ditahan dan akumulasi penyusutan. Struktur modal memiliki peran penting bagi perusahaan secara keseluruhan, karena dengan struktur modal, perusahaan dapat menilai kinerja perusahaan dan mampu mengambil keputusan untuk mengembangkan usahanya.

Struktur modal optimum menurut pendekatan konservatif adalah struktur modal yang menggunakan modal pinjaman (debt financing) maksimum 50\% dari total modal. Sedangkan menurut pendekatan biaya modal, struktur modal optimum adalah struktur modal yang dapat meminimumkan rata-rata biaya modal perusahaan. Struktur modal banyak dipengaruhi oleh berbagi macam faktor.

Berdasarkan uraian di atas penelitian ini bertujuan untuk mengetahui dan menganalisa variabel Struktur Aktiva (SA), Profitabilitas (PF), Pertumbuhan Perusahaan (PP) dan Ukuran Perusahaan (UP) mempunyai pengaruh terhadap Struktur Modal (SM) pada perusahaan manufaktur sektor industri barang dan konsumsi di Bursa Efek Indonesia periode 2017-2019

\section{KERANGKA TEORITIS DAN PENGEMBANGAN HIPOTESIS}

Teori struktur modal (capital structure theory) menjelaskan apakah ada pengaruh perubahan struktur modal terhadap perusahaan. Martono dan Agus Harjito (2010) menyatakan, Struktur modal adalah perbandingan atau imbangan pendanaan jangka panjang perusahaan yang ditunjukkan oleh perbandingan hutang jangka panjang terhadap modal sendiri. Sedangkan menurut (Astari, Risal Rinofa, \& Mujino, 2019), Struktur modal adalah pembelanjaan permananen untuk mencerminkan hutang jangka panjang dan modal sendiri. Dalam penelitian ini variabel dependen (Y) yang digunakan adalah DER yang merupakan ratio untuk mengukur kemampuan perusahaan dalam mengembalikan hutang melalui modal sendiri. Rumus ini digunakan juga dalam penelitian (Pattiruhu, 2020).

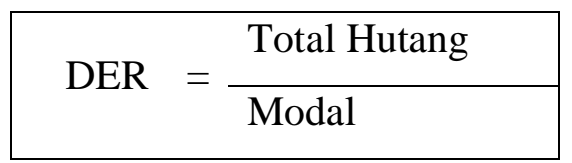

Menurut Weston dan Brigham (2005) Struktur aktiva (Asset Structure) adalah perimbangan atau perbandingan antara aktiva tetap dan total aktiva. Sedangkan menurut Syamsudin (2009) dalam penelitiannya menyatakan struktur aktiva adalah penentuan berapa besarnya alokasi untuk masing-masing komponen aktiva, baik dalam aktiva lancar maupun aktiva tetap. Struktur aktiva merupakan gambaran proporsi aktiva tetap dengan total aktiva perusahaan. Menurut hasil peelitian (Nurul Firmanullah, 2017) di mana struktur aset berpengaruh negatif terhadap struktur modal. Dapat diartikan bahwa jika struktur aset tinggi maka struktur modal akan rendah.

Struktur aktiva adalah perimbangan atau perbandingan antara aktiva tetap dan total aktiva, yang dapat menentukan besarnya alokasi dana untuk masingmasing komponen aktiva, baik aktiva lancar maupun aktiva tetap. 
Struktur Aktiva $=\frac{\text { Aktiva Tetap }}{\text { Total Aktiva }}$

Menurut Hanafi (2004) mengemukakan bahwa profitabilitas adalah kemampuan perusahaan untuk menghasilkan keuntungan (profitabilitas) pada tingkat penjualan, aset, dan modal saham tertentu sedangkan menurut I Made Sudana (2011) Profitabilitas adalah kemampuan perusahaan untuk menghasilkan laba dengan menggunakan sumber-sumber yang dimiliki seperti aktiva, modal atau penjualan perusahaan. Machfoedz dalam (Syafril, 2018) mendefinisikan rasio keuntungan (profitability), yaitu rasio untuk mengukur efektivitas operasi perusahaan dalam menghasilkan keuntungan.

Profitabilitas adalah hasil akhir dari sejumlah kebijakan dan keputusan yang dilakukan oleh perusahaan. Profitabilitas adalah kemampuan perusahaan memperoleh laba dalam hubungan dengan penjualan total aktiva maupun modal sendiri. Dalam penelitian ini diukur menggunakan ROE yang menunjukkan kemampuan perusahaan dalam menghasilkan kuntungan dengan memanfaatkan aktiva yang dimiliki seperti aktiva, modal atau penjualan perusahaan.

$$
\text { ROE }=\frac{\text { Laba Setelah Pajak }}{\text { Total Ekuitas }}
$$

Pertumbuhan yang tinggi akan memiliki lebih banyak pilihan yang riil untuk investasi dimasa depan dibandingkan dengan perusahaan yang memiliki pertumbuhan yang rendah. Pertumbuhan aset dihitung sebagai persentase perubahan aset pada saat tertentu terhadap tahun sebelumnya (Saidi, 2004). Perusahaan dengan tingkat pertumbuhan yang tinggi lebih banyak membutuhkan dana di masa depan, terutama dana eksternal untuk memenuhi kebutuhan investasinya atau untuk membiayai pertumbuhannya (Indrajaja, 2011)

Pertumbuhan perusahaan adalah perubahan (penurunan atau peningkatan) total aktiva yang dimiliki oleh perusahaan, pertumbuhan perusahaan yaitu perusahaan yang memiliki kesempatan untuk mencapai tingkat yang tinggi. Pertumbuhan perusahaan diukur dengan rumus sebagai berikut:

$\begin{aligned} & \text { Pertumbuhan } \\ & \text { Perusahaan }\end{aligned}=\frac{\text { Total Aset }(\mathrm{t})-\text { Total Aset }(\mathrm{t}-1)}{\text { Total Aset }(\mathrm{t}-1)}$

Ukuran perusahaan (Company Size) mengambarkan besar kecilnya suatu perusahaan yang ditunjukkan oleh total penjualan, total aktiva, jumlah penjualan, rata-rata tingkat penjualan dan rata-rata aktiva sehingga diketahui nilai perusahaan tersebut. Besar kecilnya ukuran perusahaan akan berpengaruh terhadap struktur modal, semakin besar suatu perusahaan akan mempunyai tingkat pertumbuhan yang tinggi demikian sebaliknya pada saat pertumbuhan perusahaan menurun makan tingkat perusahaan menurun juga. Menurut Riyanto (2001), Ukuran perusahaan menggambarkan besar kecilnya suatu perusahaan yang ditunjukan pada total aset, jumlah penjualan, rata-rata penjualan dan rata-rata total aset. Semakin 
besar ukuran perusahaan, maka biaya operasionalnya akan semakin tinggi dan membutuhkan modal yang sangat besar pula sehingga ada kecenderungan bahwa semakin besar suatu perusahaan maka akan semakin besar pula jumlah hutangnya . Oleh sebab itu perusahaan besar cenderung memiliki tingkat leverage yang lebih besar dari perusahaan kecil. Hasil penelitian (Yushinta \& Suryandhari, 2010) menyatakan bahwa ukuran perusahaan berpengaruh secara signifikan terhadap struktur modal.

Penelitian (Desiana Dinda Nur Azizah, dkk, 2020) menyatakan bahwa ukuran perusahaan merupakan perimbangan besar kecilnya perusahaan yang didapat dengan bervariasi hal antara lain yakni keseluruhan pemasaran, keseluruhan aktiva dan rata-rata tahap pemasaran perusahaan. Ukuran perusahaan adalah suatu size perusahaan yang dapat menetukan kemampuan perusahaan dalam menghasilkan laba (Astari, Risal Rinofa, \& Mujino, 2019). Rasio Ukuran perusahaan dapat diukur dengan rumus sebagai berikut:

\section{Ukuran Perusahaan $\quad=\log$ Total Aset}

Penelitian ini dimaksudkan untuk mengetahui pengaruh struktur aktiva, profitabilitas, pertumbuhan peurusahaan dan ukuran perusahaan terhadap struktur modal.

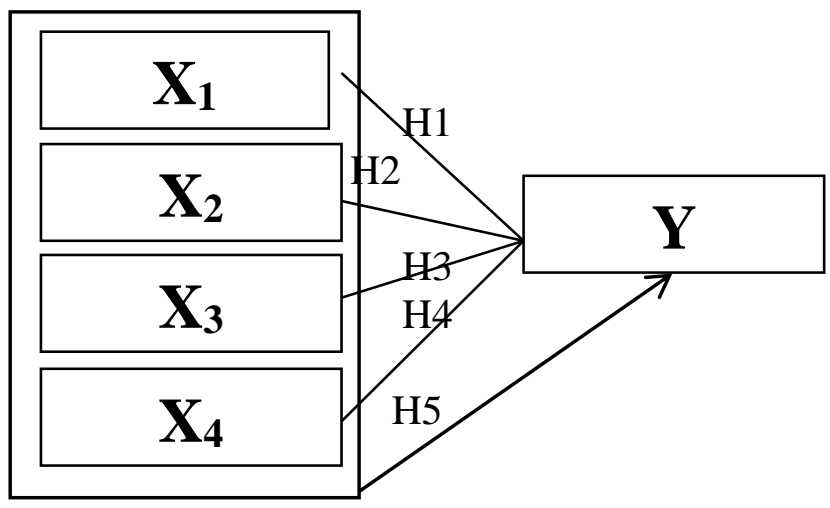

Keterangan :

$\mathrm{X} 1=$ Struktur Aktiva $\quad \mathrm{X} 2=$ Profitabilitas X3 $=$ Pertumbuhan Perusahaan

X4= Ukuran Perusahaan

$\mathrm{Y}=$ Struktur Modal

\section{METODE RISET}

Menurut Umar (2008:5), desain penelitian merupakan kerangka kerja untuk merinci hubungan-hubungan antara variabel terkait dalam suatu penelitian. Ditinjau dari tujuannya, penelitian ini dikategorikan kedalam penelitian pengujian hipotesis. Hipotesis adalah jawaban sementara atas suatu permasalahan penelitian yang kebenaran masih perlu diuji (Kountur, 2009:67). Penelitian ini bertujuan 
untuk melihat seberapa jauh independen variabel mempengaruhi dependen variabel. Dalam hal ini melihat seberapa besar pengaruh struktur aktiva, profitabilitas, pertumbuhan perusahaan dan ukuran perusahaan terhadap struktur modal. Populasi adalah wilayah yang generalis yang terdiri atas objek atau subjek yang mempunyai kualitas dan karakteristik tertentu yang ditetapkan oleh peneliti, untuk dipelajari dan ditarik kesimpulannya, Subiyanto dalam Marentek, 2015. Populasi dalam penelitian ini adalah perusahaan manufaktur sektor industri barang dan konsumsi yang terdaftar di Bursa Efek Indonesia (BEI) periode 2017 - 2019 dan yang menerbitkan laporan keuangan lengkap (IDX, 2019).

Sampel yang digunakan sebanyak 26 perusahaan manufaktur sektor industri barang dan konsumsi yang terdaftar di Bursa Efek Indonesia periode 2017 - 2019. Sampel adalah bagian dari jumlah dan karakteristik dari populasi yang dipilih. Sampel pada penelitian ini diperoleh melalui metode purposive sampling yang merupakan metode penelitian dalam menentukan sampel dengan syarat khusus sesuai dengan kriteria sebagai berikut:

1) Perusahaan manufaktur yang sudah dan masih terdaftar di BEI tahun 20172019.

2) Perusahaan sampel menerbitkan laporan keuangan selama 3 tahun berturutturut yaitu tahun $2017-2019$.

3) Perusahaan memiliki data lengkap yang diperlukan dalam penelitian pada periode penelitian tahun 2017-2019.

\section{ANALISA DATA DAN PEMBAHASAN}

Hasil analisis deskriptif penelitian sebagai berikut:

Tabel 4.1. Statistik Diskriptif

\begin{tabular}{llllll}
\hline & N & Minimum & Maximum & Mean & Std. Deviation \\
& & & & & \\
\hline SA (X1) & 78 & 0,0592 & 0,7445 & 0,357506 & 0,1506705 \\
PF (X2) & 78 & $-0,0597$ & 0,6427 & 0,011138 & 0,0757209 \\
PP (X3) & 78 & $-0,9991$ & 0,5617 & 0,077929 & 0,2330859 \\
UP (X4) & 78 & 21,8218 & 32,2010 & 28,744471 & 1,9380143 \\
SM (Y) & 78 & 0,0906 & 2,9095 & 0,748073 & 0,5473242 \\
Valid N (listwise) & 78 & & & & \\
\hline
\end{tabular}

* Corresponding author's e-mail: syafril99riau@gmail.com 
Berdasarkan hasil struktur aktiva di atas dapat diketahui bahwa nilai maksimum struktur aktiva sebesar 0,7445 sedangkan minimum sebesar 0,0592 dengan nilai rata-rata 0,3575 pada standar deviasi 0,1506 . Di mana nilai rata-rata lebih besar dari standar deviasi yaitu 0,3575 > 0,1506 yang menunjukkan bahwa nilai struktur modal bersifat homogen.

Untuk hasil profitabilitas di atas menunjukkan bahwa nilai maksimum sebesar 0,6427 dan nilai minimum sebesar $-0,0597$ dengan nilai rata-rata 0,0111 yaitu lebih kecil dari nilai standar deviasi, 0,0111 <0, 0757 yang menunjukkan bahwa nilai return on equity bersifat heterogen. Hasil uji pertumbuhan perusahaan di atas dapat diketahui bahwa nilai maksimum pertumbuhan perusahaan selama periode penelitian adalah sebesar 0,5617 sedangkan untuk nilai minimum sebesar -0,9991 dengan nilai rata-rata $-0,0779$ pada standar deviasi sebesar 0,2330 . Hal tersebut menunjukkan nilai rata-rata lebih kecil dari nilai standar deviasi yaitu 0,0779 < 0,2330, hal ini menunjukkan bahwa pertumbuhan perusahaan bersifat heterogen. Sedangkan hasil uji ukuran perusahaan di atas dapat diketahui bahwa ukuran perusahaan memiliki nilai minimum yang tercatat sebesar 21,8218 dan nilai maksimum sebesar 32,2010. Pada sampel penelitian ini ukuran perusahaan berkisar dari 21,8218 hingga 32,2010, dengan nilai rata-rata 28,7444 pada standar deviasi sebesar 1,9380 di mana nilai rata-rata lebih besar daripada standar deviasi yaitu 28,7444 > 1,9380 yang menunjukkan bahwa nilai ukuran perusahaan bersifat homogen. Adapun hasil uji statisktik struktur modal di atas dapat diketahui bahwa nilai maksimum 2,9095 dan nilai minimum sebesar 0,0906 dengan nilai rata-rata sebesar 0,7480 pada standar deviasi sebasar 0,5473 . Nilai rata-rata struktur modal lebih besar dari standar deviasi yaitu $0,7480>0,5473$ yang menunjukkan bahwa nilai struktur modal bersifat homogen.

Hasil uji normalitas Kolmogorov-Smirnov dengan SPSS dapat dilihat pada tabel di bawah :

Tabel 4.2 Uji Normalitas

\begin{tabular}{|c|c|c|}
\hline \multicolumn{3}{|c|}{ Unstandardized Residual } \\
\hline \multirow[t]{2}{*}{$\overline{\mathrm{N}}$} & & 78 \\
\hline & Mean & $0 \mathrm{E}-7$ \\
\hline \multirow[t]{2}{*}{ Normal Parameters ${ }^{\mathrm{a}, \mathrm{b}}$} & $\begin{array}{l}\text { Std. } \\
\text { Deviation }\end{array}$ & 0,51053735 \\
\hline & Absolute & 0,148 \\
\hline \multirow[t]{2}{*}{ Most Extreme Differences } & Positive & 0,148 \\
\hline & Negative & $-0,068$ \\
\hline Kolmogorov-Smirnov Z & & 1,309 \\
\hline Asymp. Sig. (2-tailed) & & 0,065 \\
\hline
\end{tabular}

Sumber: Data SPSS diolah, 2020

Dari tabel uji di atas dihasilkan nilai Kolmogorov-Smimov Z sebesar 1,309 dan nilai Asymp.Sig. (2-tailed) sebesar 0,065 dapat disimpulkan bahwa data terdistribusi normal karena nilai Asymp.Sig. (2-tailed) di atas 0,05. 
Jurnal Akuntansi Berkelanjutan Indonesia - Vol. 4, No. 1, Jan 2021 - Syafril \& Fahmi

Hasil uji autokorelasi dapat dilihat sebagai berikut:

Tabel 4.3 Uji Autokorelasi

\begin{tabular}{|c|c|c|c|}
\hline Model & $\mathrm{R}$ & R Square & $\begin{array}{l}\text { Adjusted R Square Std. Error of theDurbin-Watson } \\
\text { Estimate }\end{array}$ \\
\hline 1 & $0,360^{\mathrm{a}}$ & 0,130 & 0,5243381 \\
\hline
\end{tabular}

Berdasarkan tabel di atas dapat diketahui bahwa nilai DW adalah 1,717. Nilai tersebut akan dibandingkan dengan tabel DW dengan jumlah sampel 78, dapat diperoleh nilai DW > DU dan (4-DW) > DU adalah 1,717>1,526 dan 2,283) > 1,526, demikian hasil di atas menunjukkan bahwa model regresi tersebut menunjukkan tidak adanya autokorelasi.

Uji heteroskedastisitas dapat dilakukan dengan uji glesjer, hasil uji dapat dilihat tabel :

Tabel 4.4 Uji Heterokedasitas

\begin{tabular}{|c|c|c|c|c|c|c|}
\hline \multicolumn{7}{|c|}{ Coefficients $^{\mathrm{a}}$} \\
\hline \multirow[t]{3}{*}{ Model } & & \multicolumn{2}{|c|}{ Unstandardized Coefficients } & \multirow{2}{*}{$\begin{array}{l}\text { Standardized } \\
\text { Coefficients }\end{array}$} & \multirow[t]{3}{*}{$\mathrm{t}$} & \multirow[t]{3}{*}{ Sig. } \\
\hline & & & & & & \\
\hline & & $\mathrm{B}$ & Std. Error & Beta & & \\
\hline \multirow{5}{*}{1} & (Constant) & 0,384 & 0,577 & & 0,664 & 0,509 \\
\hline & $\mathrm{SA}(\mathrm{X} 1)$ & 0,577 & 0,234 & 0,275 & 2,469 & 0,160 \\
\hline & $\mathrm{PF}(\mathrm{X} 2)$ & $-0,230$ & 0,527 & $-0,055$ & $-0,436$ & 0,664 \\
\hline & $\mathrm{PP}(\mathrm{X} 3)$ & 0,272 & 0,178 & 0,200 & 1,528 & 0,131 \\
\hline & $\mathrm{UP}(\mathrm{X} 4)$ & $-0,007$ & 0,020 & $-0,045$ & $-0,372$ & 0,711 \\
\hline
\end{tabular}

a. Dependent Variable: Abs_RES

Berdasarkan tabel di atas menunjukkan bahwa variabel struktur aktiva (SA) memiliki nilai signifikansi 0,160, variabel profitabilitas (PF) 0,664, pertumbuhan perusahaan (PP) 0,131dan ukuran perusahaan (UP) 0,711 maka dapat disimpulkan tidak terjadi heteroskedastisitas.

Hasil uji multikolinieritas dapat dilihat dari tabel di bawah:

Tabel 4.5 Uji Multikolinieritas

\begin{tabular}{|c|c|c|c|}
\hline \multirow[t]{2}{*}{ Model } & \multicolumn{3}{|l|}{$\begin{array}{l}\text { Collinearity } \\
\text { Statistics }\end{array}$} \\
\hline & Tolerance & VIF & \\
\hline (Constant) & & & \\
\hline $\mathrm{SA}(\mathrm{X} 1)$ & 0,975 & & 1,026 \\
\hline $\mathrm{PF}$ (X2) & 0,759 & & 1,317 \\
\hline PP (X3) & 0,704 & & 1,421 \\
\hline UP (X4) & 0,833 & & 1,201 \\
\hline
\end{tabular}

Berdasarkan hasil uji multikolinieritas di atas menunjukkan bahwa semua variable bebas memiliki nilai tolerance $\geq 0,10$ dan nilai VIF $\leq 10$, dapat

* Corresponding author's e-mail: syafril99riau@gmail.com 
disimpulakan bahwa semua variabel bebas tidak terjadi permasalahan multikolinieritas.

Analisis regresi linear berganda adalah mengukur kekuatan hubungan antara dua variabel atau lebih dan juga menunjukan arah hubungan antara variabel dependen dengan independen. Hasil uji analisis regresi linear berganda dapat dilihat ditabel di bawah:

Table 4.6 Hasil Uji Regresi Linear Berganda

\begin{tabular}{|c|c|c|c|c|c|c|c|c|}
\hline \multirow[t]{2}{*}{$\overline{\text { Model }}$} & & \multicolumn{2}{|c|}{$\begin{array}{l}\text { Unstandardized } \\
\text { Coefficients }\end{array}$} & \multirow{2}{*}{$\begin{array}{l}\text { Standardized } \\
\text { Coefficients } \\
\text { Beta } \\
\end{array}$} & \multirow[t]{2}{*}{$\mathrm{T}$} & \multirow[t]{2}{*}{ Sig. } & \multicolumn{2}{|c|}{ Collinearity Statistics } \\
\hline & & $\mathrm{B}$ & Std. Error & & & & Tolerance & VIF \\
\hline \multirow{5}{*}{1} & (Constant) & ,156 & ,992 & & , 157 & ,876 & & \\
\hline & SA (X1) & 1,202 & ,402 & ,331 & 2,992 & ,004 & ,975 & 1,026 \\
\hline & PF (X2) & 658 & ,906 & ,091 & ,727 & ,470 & ,759 & 1,317 \\
\hline & PP (X3) &,- 122 & ,306 &,- 052 &,- 398 & 692 & ,704 & 1,421 \\
\hline & UP (X4) & ,006 & 034 & ,020 &, 170 & ,866 & 833 & 1,201 \\
\hline
\end{tabular}

Sumber: Data SPSS diolah, 2020

Berdasarkan hasil uji regresi linear berganda di atas dapat diketahui model persamaan regresi linear berganda sesuai dengan penelitian ini sebagai berikut :

$\mathrm{Y}=0,156+1,202 \mathrm{SA}+0,658 \mathrm{PF}-0,122 \mathrm{PP}+0,006 \mathrm{UP}+\mathrm{e}$

Berdasarkan nilai koefisien regresi struktur aktiva 1,202, profitabilitas 0,658 dan ukuran perusahaan 0,006 dapat diartikan bahwa jika struktur modal, profitabilitas dan ukuran perusahaan semakin tinggi maka akan berbanding lurus dengan tingkat struktur modal namun untuk besarnya nilai koefisien regresi pertumbuhan perusahaan yaitu -0,122, maka akan terjadi sebaliknya. Jika pertumbuhan perusahaan menurun akan berakibat naiknya struktur modal.

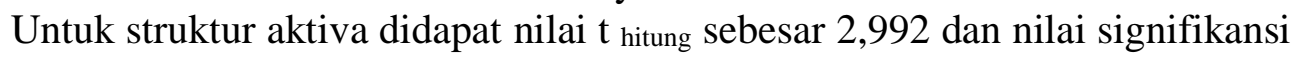
sebesar 0,004 < 0,05 maka dapat disimpulkan bahwa kedua variabel memiliki hubungan yang positif. Dapat diartikan bahwa jika pertumbuhan struktur aktiva semakin tinggi maka akan berbanding lurus terhadap struktur modalnya. Pertumbuhan struktur aktiva bisa berasal dari modal asing (debt) maupun dari modal sendiri (equity) sesuai keputusan dari manajemen perusahaan. Berdasarkan hal tersebut, maka hasil uji hipotesis dapat dinyatakan bahwa $\mathrm{H} 1$ adalah diterima.

Untuk profitabilitas nilai $t$ hitung sebesar 0,727 dan nilai signifikansi sebesar $0,470>0,05$ maka dapat disimpulkan bahwa nilai koefisien regresi profitabilitas tidak berpengaruh signifikan terhadap struktur moda pada perusahaan manufaktur sektor industri barang dan konsumsi yang terdaftar di Bursa Efek Indonesia periode tahun 2017 - 2019. Pertumbuhan Profitabilitas akan mendukung pertumbuhan dari Struktur Modal dari hasil usaha perusahaan itu sendiri. Salah satu sumber modal perusahaan adalah laba yang digunakan untuk menambah modal perusahaan. Pertumbuhan perusahaan yang tinggi akan memerlukan banyak modal untuk membiayai operasional perusahaan. Oleh sebab itu semakin tinggi pertumbuhan perusahaan maka akan menguras modal perusahaan saat ini. Untuk itu perusahaan harus mencari sumber pendanaan yang baru agar pertumbuhan perusahaan dapat 
diwujudkan. Berdasarkan hal tersebut, maka hasil uji hipotesis dapat dinyatakan bahwa $\mathrm{H} 2$ adalah tidak diterima

Untuk pertumbuhan perusahaan memiliki nilai $t_{\text {hitung }}$ sebesar $-0,398$ dan nilai signifikansi sebesar 0,692>0,05 maka dapat diketahui bahwa pertumbuhan perusahaan tidak berpengaruh signifikan terhadap struktur modal pada perusahaan manufaktur sektor industri barang dan konsumsi yang terdaftar di Bursa Efek Indonesia periode tahun 2017 - 2019. Berdasarkan hal tersebut, maka hasil uji hipotesis dapat dinyatakan bahwa $\mathrm{H} 3$ adalah tidak diterima.

Untuk ukuran perusahaan didapat nilai $t$ hitung sebesar 0,170 dan nilai signifikansi sebesar 0,866>0,05 maka dapat disimpulkan bahwa ukuran perusahaan tidak berpengaruh signifikan terhadap struktur modal pada perusahaan manufaktur sektor industry barang dan konsumsi yang terdaftar di Bursa Efek Indonesia periode tahun 2017 - 2019. Kenaikan Ukuran Perusahaan dari skala kecil menjadi skala besar tentu memerlukan kenaikan biaya operasional untuk menghasilkan keuntungan dari operasional perusahaan. Untuk menopang kenaikan biaya operasional maka perusahaan membutuhkan tambahan modal yang bisa berasal dari modal sendiri maupun modal asing. Hal ini sesuai dengan Capital Structure Theory bahwa perusahaan besar cenderung memiliki tingkat leverage yang lebih besar dari perusahaan kecil. Berdasarkan hal tersebut, maka hasil uji hipotesis dapat dinyatakan bahwa $\mathrm{H} 4$ adalah tidak diterima

Tabel 4.7 Uji F

\begin{tabular}{|l|l|r|r|r|r|r|}
\hline \multicolumn{2}{|l|}{ Model } & Sum of Squares & Mf & Mean Square & F & Sig. \\
\hline \multirow{4}{*}{1} & Regression & 2,996 & 4 &, 749 & 2,725 & $0,036^{\mathrm{b}}$ \\
\cline { 2 - 7 } & Residual & 20,070 & 73 &, 275 & & \\
\cline { 2 - 7 } & Total & 23,066 & 77 & & & \\
\hline \multicolumn{2}{l}{ Sumber: Data SPSS dilah, 2020 } \\
\hline
\end{tabular}

Berdasarkan tabel di atas diperoleh nilai $\mathrm{F}$ sebesar 2,725 dan nilai signifikansi sebesar $0,036<0,05$. Artinya adanya pengaruh variabel independen yaitu struktur aktiva, profitabilitas, pertumbuhan perusahaan dan ukuran perusahaan secara simultan (bersama-sama) berpengaruh terhadap struktur modal. Berdasarkan hal tersebut, maka hasil uji hipotesis dapat dinyatakan bahwa $\mathrm{H} 5$ adalah diterima.

Hasil analisis koefisiensi determinasi (Adjusted $R$ Square) sebesar 0,082 dapat disimpulkan besarnya variabel independen (bebas) mempengaruhi struktur modal adalah sebesar 0,082 atau $8,2 \%$ sisanya dipengaruhi oleh faktor lain di luar penelitian.

\section{KESIMPULAN}

Penelitian ini bertujuan untuk mengetahui pengaruh secara parsial dan simultan variabel Sturktur Aktiva, Profitabilitas, Pertumbuhan Perusahaan dan Ukuran Perusahaan terhadap Struktur Modal Pada Perusahaan Manufaktur Sektor Industri Barang Dan Konsumsi di Bursa Efek Indonesia Periode 2017-2019.

Berdasarkan hasil penelitian ini diketahui bahwa secara parsial variabel struktur aktiva mempunyai pengaruh secara signifikan terhadap struktur modal, sedangkan variabel profitabilitas, pertumbuhan perusahaan dan ukuran perusahaan 
tidak berpengaruh signifkan terhadap struktur modal. Secara simultan variabel indpenden strutur aktiva, profitabilitas, pertumbuhan perusahaan dan ukuran perusahaan mempunyai pengaruh signifikan terhadap struktur modal pada perusahaan manufaktur sektor industri barang dan konsumsi terhadap struktur modal di Bursa Efek Indonesia Periode 2017-2019.

Penelitian ini tentu memiliki banyak kekurangan dan masih banyak ruang bagi peneliti lain untuk meng-eksplore lebih dalam lagi dengan menambahn beberapa variabel lain yang belum dibahas dalam penelitian ini.

\section{DAFTAR PUSTAKA}

Astari, Yola, dkk. (2019). Pengaruh Struktur Modal dan Profitabilitas Terhadap Nilai Perusahaan dengan Ukuran Perusahaan Sebagai Moderasi (Studi Kasus Pada Perusahaan Property dan Real Estage Yang Terdaftar Di Bursa Efek Indonesia Periode 2014-2018). Jurnal Ilmiah MEA, STIEMB, Vol.3 No.3. page 191-201

Azizah, Desiana Dinda Nur, dkk. (2020). Pengaruh Board Independen, Firm Size, Debt to Equity Ratio, Net Profit Margin Terhadap Kebijakan Deviden Pada Perusahaan ( Sub Sektor Makanan dan Minuman Yang Terdaftar di BEI 2002018). Jurnal Riset Akuntansi dan Komputerisasi Akuntansi, Vol.11 No.1

Bringham, E.F \& Houston, J.F. (2001). Manajemen Keuangan. (edisi 8). Jakarta: Erlangga.

, E,F \& Weston, J,F. (2005). Dasar-Dasar Manajemen Keuangan (edisi 9). Jakarta: Erlangga.

, E.F \& Houston, J.F. (2006). Dasar-Dasar Manajemen Keuangan, (edisi 10). Jakarta: Salemba Empat.

Hanafi, Mamduh, M. (2004). Manajemen Keuangan. Edisi Pertama. Jogjakarta: BPFE.

Hidayat, Riza Fatoni. (2013). Analisis Faktor-Faktor yang Mempengaruhi Struktur Modal pada Perusahaan Manufaktur Terdaftar di Bursa Efek Indonesia Periode 2007-2011. Jurnal Diponegoro of Accounting, Vo..2, No.2.

Husnan, Suad. (2004). Manajemen Keuangan, Teori dan Penerapan. BPFE, Yogyakarta

Indrajaya, dkk. (2011). Pengaruh Struktur Aktiva, Ukuran Perusahaan, Tingkat Pertumbuhan, Profitabilitas dan Risiko Bisnis Terhadap Struktur Modal”. Studi Empiris Pada Perusahaan Sektor Pertambangan yang Listing di Bursa Efek Indonesia Periode 2004-2007. Jurnal Ilmiah Akuntansi. No. 06, Tahun ke 2, September-Desember 2011.

I Made Sundana. (2011). Manajemen Keuangan Perusahaan Teori dan Praktik. Jakarta: Erlangga.

Kountur, Ronny. (2009). Metode Penelitian untuk Penulisan Skripsi dan Tesis, Edisi Revisi. Penerbit PPM, Jakarta

* Corresponding author's e-mail: syafril99riau@gmail.com 
Jurnal Akuntansi Berkelanjutan Indonesia - Vol. 4, No. 1, Jan 2021 - Syafril \& Fahmi

Marentek, Anisa Sarly. (2015). Analisis Faktor-Faktor Yang Mempengaruhi Struktur Modal Perusahaan Manufaktur Yang Terdaftar Di Bursa Efek Indonesia (Pada Perusahaan Food and Baverage Periode 2007-2010). Jurnal Berkala Ilmiah Efisien. Vol.15 No.5.

Martono dan Agus Harjito. (2010). Manajemen Keuangan. (Edisi 3). Yogyakarta, Ekonisia.

Nurul, Firmanullah Darsono. (2017). Faktor-Faktor Yang Mempengaruhi Struktur Modal Di Perusahaan Indonesia (Pada Perusahaan Manufaktur Yang Terdaftar di Bursa Efek Indonesia Tahun 2011-2014). Diponegoro Juournal Accounting, Vol.6 No.3. page 1-9

Pattiruhu, Jozef R. (2020). Analisis dan Implikasi Nilai Tukar dan Suku Bunga Bank (BI Rate) Terhadap Struktur Modal Perusahaan Industri Yang Tercatat Pada Bursa Efek Indonesia. Jurnal Ilmiah MEA, STIEMB, Vol.4 No.2, page 200-221

Riyanto, Bambang. (2001). Dasar-dasar Pembelanjaan Perusahaan. Edisi 4. Yogyakarta: BPFE.

Saidi. (2004). Faktor-faktor yang Mempengaruhi Struktur Modal pada Perusahaan Manufaktur Go Public di BEJ 1997-2000, Jurnal Bisnis dan Ekonomi.

Sugiyono. (2004). Metode Penelitian Bisnis, Alfabeta Bandung

Syafril. (2018). Pengaruh Operating Income, Net Income dan Total Asset

Terhadad Return On Asset (ROA) pada BMT Amanah Banjarmasin 1). In

Net Income Dan Total Asset Terhadap ROA. Jurnal Al-Amwal (Vol. 7, Issue 1).

Syafril. (2019). Informasi Contribution Margin Sebagai Alat Perencanaan Laba

Bagi Manajemen. Jurnal Riset Akuntansi, 3 (1)(Akuntasi Manajemen).

https://doi.org/https://doi.org/10.35141/jraj.v3i1.559

Syamsuddin. (2009). Manajemen Keuangan Perusahaan. Jakarta: PT. Raja Grafindo Persada.

Tauhid, Endah Pituriningsih, Dwi Putu Bauana Sakti. (2018). The Determinant of Optimization Management for Fixed Assets Village In East Lombok Regency, International Journal of Business and Management Invention (IJBMI), Volume 7 Issue 2, February. 2018, PP-43-49

Umar, H. (2008). Desain Penelitian Akuntansi Keperilakuan. PT Grafindo Persada, Jakart

Yushinta, Putria, Erni Suryandari. (2010). Analisa Faktor-Faktor Yang Mempengaruhi Struktur Modal (Studi Empiris Pada Perusahaan Manufaktur di Bursa Efek Indonesia. Jurnal Akuntansi dan Investasi. Vol.11 No2, Hal: $179-188$

http://www.idx.co.id/

* Corresponding author's e-mail: syafril99riau@gmail.com 